\title{
2 Ownership transformations in Poland and Ukraine
}

\author{
Svitlana Chugaievska, Rafat Wista and \\ Andrzej Nowosad
}

\subsection{Introduction}

In August 1991, Ukraine gained independence for the first time in its history. In October 1991, the first completely free parliamentary elections since World War II were held in Poland. Changes to the socio-economic system commenced (it can be said symbolically) in the same year in Poland and Ukraine, and they had a common denominator - the Gross Domestic Product (GDP) per capita ${ }^{1}$ in both countries was at the same level (9.5 thousand USD, PPP, ${ }^{2}$ in prices of the year $2011^{3}$ ). However, it is difficult to find other similarities.

Poland, in the early 1990s, had at its disposal several basic relatively scholarly institutions: its own currency, a central bank, the spirit and pragmatism of the free market, private ownership, its own state budget, a solidarityintellectual elite based on the working class and a dissident intelligentsia, capable of developing and implementing reforms with the help of US professionals, and access to relatively reliable statistical data.

Ukraine, after the fall of the Union of Soviet Socialist Republics (hereinafter: the USSR), in the early 1990s, had no experience in building a market economy institution. Ukrainian society, brought up in a totalitarian system, had to face the extremely difficult task of creating a market economy institution and implementing democratic principles of the rule of law in a post-Soviet sphere of socio-economic development. It never possessed the conditions essential for the creation of democratic institutions. It is worth recalling that it went directly from a system of authoritarian monarchy (tsardom-autocracy) in Tsarist Russia - after the February Revolution (Russian: Февра́льская револю́ция, 1917) and the October Revolution (the October Revolution, officially known in Soviet historiography as the Great October Socialist Revolution, 1917), and the killing of Tsar Nikolai II Alexandrovich Romanov (May 18 [O.S. 6 May], 1868-July 17,1918) and the entire Tsarist-Imperial family, Russia (followed by Russian-occupied Ukraine) immediately began to build a communist state. At a time when these events took place, it was a modern idea, and the doctrine of the state was to be based on social justice, the protection used by the owners of the workers' 
capital, but quickly became the basis for one of the world's most terrifying and repressive totalitarian regimes.

The dissolution of the USSR in the 1990s surprised many in the republics that were part of the USSR as well as the leaders of the USSR itself. For the leaders of Ukraine, Russia and Belarus, however, it was no surprise because they initiated and signed the dissolution of the USSR, even though this was a surprise to many of the citizens of the USSR. Free market institutions, private property, financial markets and individual entrepreneurship were created from scratch, without the help of American specialists.

The many difficulties in institutional changes in Ukraine and Poland have been the subject of extensive research, and the basic literature on the subject has been presented in Chapter 1. The aim of this chapter is to provide a synthetic discussion of the process of ownership transformations in Poland and Ukraine, and the role of the capital market in the process of ownership between 1990 and 2015. The development of two selected institutions of the economy - private property and the capital market, a mechanism supporting privatization - is the main area of analysis in this chapter.

\subsection{Privatization}

The process of the ownership structure transformations in the Polish and Ukrainian economies is an important area of major institutional changes that took place in the sectors studied during the period of systemic transition from a communist regime, and a centrally planned economy, to a democratic regime and a free market. Both economies experienced nationalization at that time, a form of state-expropriation through which the state acquired the rights and ownership of land, businesses and capital under a legal act. Nationalization was carried out mainly without payment of compensation for existing owners, or for a symbolic remuneration. In Bolshevik Russia, in 1918, after the revolution, private property was nationalized without any compensation for private companies-owners, which was also extended to soviet-occupied Ukraine in the 1920s. (The opposite of nationalization is privatization.)

In Poland, nationalization was implemented in 1946 on the basis of the Law on the Acquisition of the Basic Branches of the National Economy (Act of 1946) and the Decree amending the Act, dated January 3, 1946, on the acquisition of the main branches of the national economy by the state. The processes of nationalization were accompanied, both in Poland and in Ukraine, by expropriation and confiscation, that is, a forced (without compensation or payment) deprivation of private property. These processes were conducted under the banner of building communism. The Communist Party manifesto announced that "communists can express their theory in one phrase: 'destruction of private property"' (знищенння приватної власності). In Ukraine, the processes of nationalization and expropriation began in 1919 and was a continuation of the process that began in Russia in 
1918, on the basis of a decree of the High Council of the People's Economy (Вища Рада Народного Господарства) ${ }^{4}$ and whose guidelines were sent to Ukraine, after its seizure by soviet troops, to the Ukrainian Council for The People's Economy (Українська Рада Народного Господарства). ${ }^{5}$ In the process of nationalization and expropriation, the Ukrainian Council led the work of 45 faculties (відділ) with an extensive network of departments, management and centers and 10,720 regional units of active property collection. It was an intensive process which resulted in many victims and was concluded in 1921.

After the collapse of the USSR, both in Poland and in Ukraine, one of the most important tasks of the transformation was the privatization of stateowned enterprises and the privatization of property in general.

\subsubsection{Privatization in Poland}

Privatization in Poland, which began in 1990, was a number of diverse actions aimed at changing the ownership of private property while reducing state involvement in the economy (Bałtowski 2002: 17).

In July 1990, a law on the privatization of state-owned enterprises was passed in Poland ${ }^{6}$ - the basic legal act triggering the process of ownership transformation in the country.

In the following years, laws were passed: on the management of agricultural property of the State Treasury, ${ }^{7}$ on the ownership transformations of certain state-owned enterprises of particular importance for the economy, ${ }^{8}$ on national investment funds (NFI) and their privatization. ${ }^{9}$ These regulations enabled proprietary transformations using three basic privatization approaches:

1 Capital privatization - consisting of the conversion of a state-owned enterprise into a single-owner company of the State Treasury and subsequently its privatization by selling shares or stakes (often using the capital market) or transferring them to the NFI (National Investment Fund)

2 Privatization by liquidation - consisting of the liquidation of a stateowned enterprise for the sale of its assets, transfer to a company or putting it into non-gratuitous use

3 The inclusion of assets in the Agricultural Property Resources of the State Treasury - consisting of the liquidation of an agricultural enterprise and the acquisition of its assets by the Agricultural Property Agency of the State Treasury (Agencja Własności Rolnej Skarbu Państwa)

Poland when initiating, in the early 1990s, the process of ownership transformation encountered difficulties due to the lack of a bona fide register of state property. ${ }^{10}$ Most of the production assets were the responsibility of 
49 provincial offices (Urząd Wojewódzki). The grassroots initiatives of the workers' council or of the director of a state enterprise were not generally blocked by the provincial administration. For example, privatization in the Jelenia Góra region covered about $53 \%$ of state-owned enterprises by the end of 1995.

The most dynamic was the privatization processes in 1992 and 1994. Information about ownership transformations at the provincial level did not always go to the State Treasury Ministry, and if it was transmitted, the ministry did not maintain any database on the original formal and legal status of privatized assets, the number of transformations carried out and many other detailed bits of information on the basis of which a credible, myth-free image of the dynamics of privatization in Poland could have been created.

A much more reliable picture of the ownership transformation processes emerges from those ownership changes that took place directly under the supervision of the Ministry of the Treasury (Resort Skarbu Państwa). The Statistical Bulletin of the GUS (Biuletyn Statystyczny GUS) from 1991 reports that there were 8,453 state-owned enterprises operating at the end of 1990 in Poland. Between August 1, 1990, and the end of December 2015, 6,003 state-owned enterprises were included in the ownership transformation programs. At the end of 2015, the number of state-owned enterprises was 41 , including 19 active business enterprises. ${ }^{11}$

Between 1991 and 2015, 1,756 state-owned enterprises were commercialized (29.3\% of all converted enterprises), 2,308 applications for direct privatization (38.4\% of all converted enterprises) were commercialized, and 1,939 state-owned enterprises were liquidated due to their poor financial condition under Article 19 of the Law on the privatization of state-owned enterprises in the absence of opposition from the Ministry of Property Transformation or the Ministry of the Treasury $(32.3 \%$ of the total companies by at the end of 1990). ${ }^{12}$ The grand total was some 6,003 state-owned enterprises. In 2013, the GUS ${ }^{13}$ provided a specific number, that is, 7,555 entities that were covered by the privatization process between 1990 and 2012 .

As a result of the commercialization of state-owned enterprises between 1990 and 2012, 1,710 companies were established..$^{14}$ Most companies were created in the Śląskie (306) and Mazowieckie (230) provinces, the least in the Lubuskie (35) and Warmińsko-Mazurskie (37). At the end of 2012, 1,047 companies were operating as a result of commercialization (in 2011 - 1097), including 178 single-member Companies of the State Treasury (there were 228 a year earlier).

At the end of 2015, the Minister of the State Treasury (Minister Skarbu Państwa) exercised ownership rights in 206 companies which were conducting economic activity (excluding 67 companies with only employee shares). The State Treasury's share was $100 \%$ in 87 companies out of the 206 "active" operating companies, in 29 companies the State Treasury held a majority stake, and in 90 companies the State Treasury held a minority stake. 
In 217 companies, legal proceedings were conducted aimed at terminating their operations: in 73 companies the liquidation process was continuing, 68 companies went bankrupt, and 76 companies were not in operation. ${ }^{15}$

The experience of 25 years of economic transformation allows an overall positive assessment of Polish privatization. Although the Ministry of the Treasury did not possess, in the 1990s, a structured list of state-owned enterprises - that is, a register of its assets - the state's share as owner of the means of production between 1990 and 2015 decreased radically, according to both MSP and GUS data.

A comparison of the course and effects of Polish privatization with the same process conducted in Ukraine indicates that the path adopted and the methods used were generally appropriate. Numerous empirical studies and GUS statistics indicate that privatized companies are better managed than state-owned companies, and thus achieve better financial results. The effectiveness of the various privatization paths in Poland varies. Privatization with a strategic investor was the most effective method. The path of labor privatization was significantly less effective. By far the least effective method of ownership transformation turned out to be the NFI Programs Programs of Universal Privatization (Stępniak-Kucharska 2015: 142).

One of the criticisms of the privatization process in Poland was the fact that the rules of privatization were not clearly defined, which led to numerous abuses. The state retained the right to decide the fate of a company as a whole, that is to say, the liquidation, merger with another entity or its sale (Zalewa 2008: 67) and the fact of top-down privatization, not bottom-up, which resulted in an asymmetry of information among entities and transformation for private purposes used by the previous communist mangers and, above all, by the directors of enterprises and employee's councils. This process in the 1990s was commonly referred to as the "pillaging of the economy" because a company's assets were sold for symbolic quotas - that is, pennies on the dollar, regardless of the condition of the company. It is worth mentioning that in Poland since 1987 the law has allowed the possibility of converting state-owned enterprises into commercial partnership companies, provided that the shareholders will be from various state organizations (Fedorowicz 1990: 25), and the Act of 24 February 1989 on certain conditions of consolidation of the national economy contained a general declaration as to the transfer to natural and legal persons of state-owned enterprises, for the purpose of doing business ${ }^{16}$ (Guzek 1994).

The institutional framework for the privatization process was being prepared in Poland for at least five years before its formal initiation, by drafting the appropriate legislative acts. The laws were adopted under a specific recipient, and the form of the companies created was called "nomenclature companies", since it was only former communist party directors who established and conducted private activities using state assets (Gomułka 2013; Długosz 2014). It is also pointed out that for privatization purposes, a large number of institutions were established in Poland that functioned as companies and 
had the powers of ministries and were not under any real public control, such as the Agricultural Market Agency, 1990-2017, in 2017, merged with the Agricultural Real Estate Agency and transformed into the National Agricultural Support Centre; The Agricultural Property Agency of the State Treasury (1991-2017; converted in 2003 into the Agricultural Real Estate Agency; the Military Real Estate Agency (2005, transformed into the Military Property Agency in 2015); the State Coal Agency Joint Stock Company (1990, in 2003 converted into the Coal Company Joint Stock Corporation, in 2016 acquired by the Polish Mining Group Joint Stock Company), etc. It is already clear from the names of the agencies that they can be segregated by the economic sectors in which the state has retained supervision, and their task was to carry out privatization. Today, they are among the largest companies in Poland. It is worth noting that the functions, tasks and competences of such enterprises with the competence of the ministries were created as companies with public money, which is a characteristic of Polish privatization, although in Poland none of these network systems are officially referred to as an oligarchy. Nevertheless, these are networks of shadow systems, of old political arrangements and of state-policy-business-privatization links. The state apparatus has great legal, semi-legal and illegal capabilities in Poland to fight organized crime; however, the ministry-companies and their privatizations were never the subject of a criminal investigation conducted by the public prosecutor's office. The Polish security services and the judiciary not only do not combat such phenomena, but are also interested in maintaining and supporting them. "Protection" of the system according to the patron-client principle is a characteristic of the privatization era (see: Gadowska 2002; Jarosz 2004: 44; Zalewa 2008: 117).

\subsubsection{Privatization in Ukraine}

In 1991, Ukraine regained its independence and began to reform both the political and legal, as well as the economic systems. The dissolution of the Soviet Union led to the creation of more than a dozen independent states, resulting in the disintegration of dependencies within the Union of Soviet Socialist Republics, including the dissolving of dependencies between former soviet republics and the businesses operating in their territory. One of the most important challenges - institutional changes - on the path to systemic and economic change has become the privatization of the state sector - a key element of the socialist system.

The reference point for the proposed ownership transformations in Ukraine in the early 1990s was the experience of decentralizing the public sector of the economies of the Western European countries of the 1970s and 1980s. However, ownership changes in western European countries have taken place under the conditions of a structured and mature private property institution, while in Ukraine it was necessary to construct this 
institution almost from scratch, by creating adequate legal bases and forming the relevant institutions, a process which continues to this day. ${ }^{17}$

At the initial stage of the ownership transformation process - national privatization, based on the Law on the Privatization of State Property (1992) - the transfer of "property titles" to part of the state assets in the form of a new type of securities, that is, privatization coupons, was organized.

The main reasons were (1) the taking up of public and managerial functions in privatized companies by the former bureaucratic apparatus, (2) questionable valuations of companies intended for coupon privatization and (3) a profound pauperization of society. Under the conditions of hyperinflation, combined with the unpunctual payment of wages, the reprivatization coupons were often exchanged in "currency kiosks" for an amount of money equal to the cost of three to four loaves of bread.

In 1995, in the industrial processing sector of Ukraine, where the process of ownership transformation took place at the fastest pace, state-owned enterprises, nevertheless, continued to dominate. At the beginning of the ownership transformation process, they were estimated to be around 8,900 companies, that is, approximately $70 \%$ of the total number of state-owned enterprises. By 1995, 3,701 companies had been commercialized; only one of them was completely privatized. ${ }^{18}$ In 1997, the classification of legal entities changed; hence, the existing organizational and legal forms in the early 1990s and those in force after 1997 are quite difficult to compare.

In 1996, the Company register was created (Сдиний державний реєстр фізичних осіб-підприємців та громадських формувань - JPRPOU) - that is a system for collecting, accumulating and processing data on enterprises and organizations operating in all legally permitted forms of ownership. Since 1997, the process of ownership transformation has taken on a faster pace. It should be noted, however, that the consolidation of data sets concerning corporate entities was not started until 1998, hence the lack of data for 1995. Since 1996, UKRSTAT has kept a record of data for all economic operators together, in one group, without distinguishing between forms of ownership in the manufacturing processing sector. The dynamics of changes in the number of economic operators according to different forms of ownership between 2000 and $2015^{19}$ are presented in Table 2.1 .

The number of state-owned enterprises decreased significantly during the analysis period. In 2000, The State Property Fund of Ukraine (Фонд державного майна України, Fond derzhavnoho mayna Ukrayiny) reported nearly 10,000 state-owned enterprises on its balance sheet. After 15 years, this number has fallen to 4,042 companies. The increasing number of limited liability companies is explained by their attractive legal and business construction, commonly used in business activities in Ukraine. A very significant decrease in the number of public limited liability companies between 2010 and 2015 can be explained by the mass closure due to the break-up of trade relations with the Russian Federation, and a 
Table 2.1 Number of economic entities in Ukraine between 2000 and 2015 (in thousands)

\begin{tabular}{lrrrr}
\hline Indicator & 2000 & 2005 & 2010 & $2015^{20}$ \\
\hline State sector & & & & \\
- State-owned enterprises & 9.9 & 7.8 & 6.8 & 4.0 \\
- Public utility & $\ldots$ & 16.5 & 16.0 & 11.5 \\
& & & & \\
Private sector & 175.9 & 2380 & 283.7 & 201.9 \\
- Private companies (entrepreneurs) & 35.2 & 34.6 & 30.2 & 15.9 \\
- Public limited liability companies & & & \\
$\quad$ (spółki akcyjne) & 198.1 & 302.9 & 418.1 & 453.9 \\
\hline
\end{tabular}

Source: State Statistics Service of Ukraine: http://www.ukrstat.gov.ua.

strong increase in the prices of Russian raw materials (2013-2014) used by Ukrainian industry.

In 2008, the Center for Economic Development (Центр економічного розвитку, Tsentr ekonomichnoho rozvytku) based in Kyiv conducted a retrospective analysis of the effects of the privatization processes in Ukraine. During the timeframe considered, three main stages of the ownership transformation process were identified. Stage one (1992-1994) was characterized by a slow pace of privatization and the gradual buyback of previously leased state property. Stage two was mass privatization using privatization coupons (1995-1998). At this stage, the securities trading market was established, while the base of state assets intended for privatization employing privatization coupons was expanding. The main barriers to effective privatization at this stage were a low standard of living (hence the rapid resale of privatization coupons), a dearth of knowledge on the rules of how a market economy functions and hyperinflation. The third phase, from 1999 to 2004, was characterized by a decrease in the average state revenue from the sale of medium and large state property entities and a reduction in the sale of state-owned enterprises to strategic industrial investors (see Paskhaver et al. 2008: 85).

The last decade has seen the creation of large Ukrainian business groups with an agricultural, industrial and financial profile. This is linked to the formation of a new Ukrainian elite - representatives of "big business", which use the intensive involvement of foreign capital by Ukrainian companies on the external market for their modernization and expansion. The last few years have manifested a marked increase in the value of direct foreign investment in Ukraine, but also of considerable Ukrainian capital investment abroad (see: Leonov, Zhuk 2005: 135; Andriychuk 2015: 12-22).

According to data from the State Property Fund of Ukraine (Фонд державного майна України, Fond derzhavnoho mayna Ukrayiny (SPFU), a central body of executive power with special status and being administered by the Cabinet of Ukraine, in 1992-2017 more than 132,700 entities 
were privatized. Of these, 29,610 were state entities, and 103,090 were municipal property facilities. The total budgetary revenue from the privatization of state property during the analysis of ownership conversions was 67 billion UAH (SPFU 2018).

Since 2017, there has been an online platform for the sale of small privatization facilities https://prozorro.sale/ (ProZorro.Продажi). A mechanism has been put in place to block rogue entities from participating in the state property rental competition. Currently, 18,906 state-owned economic facilities are leased (as of January 2018; SPFU 2018).

At the end of 2017, 3,893 state companies were registered in the SPFU and public utility companies numbered 11,640 . The state has majority packages in approximately 500 capital companies (SPFU 2018). The issue of ownership changes of large and strategic state-owned enterprises and an increase in the efficiency of the management of Ukraine's agricultural property are still not resolved.

The current geopolitical situation and the declining average living standard create a social and economic situation and social sentiment reminiscent of those from 1995 to 1998, that is, the risk of selling off state and private assets below their fair value, and are therefore not conducive to stabilization.

In general, any assessment of the current process in the ownership transformation in Ukraine and its results is not unambiguous. Two opposing forces are clashing. On the one hand, a strong pro-market stimulus has been unleashed, which has contributed to a radical change in the political and economic system, including the construction of a private property sector from scratch, and the emergence of national production capital, which played a particularly positive role in ensuring a high pace of economic growth in the period of 2005-2008 (Chenash 2013: 55-60; Khoma, Kondakova 2013: 280-286). On the other hand, the privatization methods employed, the lack of proper control over their course and corruption caused tensions in Ukraine's social fabric. The gap between the narrow group of "winners" and a broad group of "losers" in the process of ownership transformation (Paskhaver et al. 2008) became one of the causes of the political crisis in the country - the Orange Revolution (Ukrainian: Помаранчева революція, Pomarancheva revolyutsiya) 2004 and the Euromaidan (Свромайдан, Yevromaidan) in 2013-2014.

\subsection{The capital market - a mechanism to support ownership transformation}

Long-term finance capital is understood to be one of the tools of the equity path of ownership transformation and the mechanism for converting national savings into corporate sector investments. A mature and efficient capital market is also a mechanism: economic optimization and rationality, trans-economic turnover and the financial supply for projects with above-average economic risks (new business models, new product solutions) 
The aim of this part of the chapter is to generally diagnose the potential of the Polish and Ukrainian equity and debt securities equity, as a mechanism used to increase the allocative and dynamic efficiency of the huge long-term capital finance required.

The following assumptions are made in the subsection: (1) a wellfunctioning and developed capital market contributes to economic growth and job creation, (2) companies present on the capital market as issuers of equity and/or debt securities are characterized by a higher than average intensity in R\&D activities, (3) a well-functioning and developed capital market supports fair economic turnover.

The development of the Polish capital market is closely observed by Polish and Ukrainian economists (see: Madej 1998; Krasnov 2001; Arkhireyev 2006; Harutyunyan 2017), and the results of its analysis in Poland were regularly published in the journal Rynek Kapitałowy: miesięcznik analiz polskiego rynku kapitałowego (Capital Market: a monthly analysis of the Polish capital market, 1998-2008), and by the National Bank of Poland in recurring reports entitled "The Financial Market in Poland" (1998-2018); ${ }^{21}$ in Ukraine in "Visnyk of the National Bank of Ukraine" (Вісник Національного банку України), since 1994.

\subsubsection{The Polish capital market}

Individual operating segments of the financial market have been developing in Poland since the early 1990s. The interbank market will be the first to develop the following segments: interbank deposits, treasury bills and currency exchange. In parallel with the interbank market, the market for equity and debt capital is developing within the market governed by securities trading. The main driving force behind the development of the equity market was privatization, while for the debt securities market, it was the issuing of treasury bonds.

The development of the financial capital market depends not only on economic conditions but also on the quality of created institutions - i.e. the durability and efficiency of regulatory solutions resistant to the dynamics of changes in an economic environment. Capital market institutions in the 1990s of the 20th century, just before accession to the European Community, as well as during the period of full membership of the EU's internal capital market, are characterized by high volatility.

The ratification of the Europe Agreement establishing an association between the Republic of Poland and the European Communities (1992) ${ }^{22}$ has necessitated a consistent alignment in the manner national institutions operate, in comparison with those institutions already developed in nations within the European Community. In the 1990s, with regard to the capital market, significant changes in capital market regulations were observed. These activities were linked with the development of the internal market or from the single-currency zone within the European Community. 
In 1999, the European Financial Services Action Plan (FSAP) was adopted by the European Commission. In 2000, the European Council recognized it as an important part of the so-called Lisbon Strategy. According to the original assumptions, the majority of the actions taken under the FSAP related to the capital market and retail financial services. In the preceding period, as well as during the creation of the FSAP, these areas were the least integrated with the European financial market.

The following directives adopted by the European Parliament and the Council of the EU are among the most important capital market regulations during this period: (1) regarding prospect uses (2003/71/EC), (2) regarding markets in financial instruments (Markets in Financial Instruments Directive - MiFID; 2004/39/EC), and (3) regarding transparency and information obligations (2004/109/EC). All these changes in EU capital market regulations are fully reflected in the Polish legal order, that is, in the 2005 package of laws: (1) on the trading of financial instruments, ${ }^{23}$ (2) on the public offer and conditions for the introduction of financial instruments into an organized trading venue and on public companies ${ }^{24}$ and (3) supervision of the capital market. ${ }^{25}$

Among European countries, the capital market in Poland is in tenth place ( \pm 2 places depending on the year) according to the criterion of the capitalization of companies and the value of trading in shares. ${ }^{26}$ Europe's biggest markets are currently Euronext with a market capitalization of nearly $\$ 4$ trillion and the London Stock Exchange Group with a capitalization of \$3.8 trillion at the end of 2018. The market value of listed companies on the Warsaw Stock Exchange is about USD 160 billion, and the capitalization of the Ukrainian Stock Exchange (Українська біржа, Ukrayinska birzha) is 4.4 billion USD. Similar levels of capitalization are found in the Cyprus Stock Exchange ( $\$ 3.3$ billion) and the Ljubljana Stock Exchange ( $\$ 7.1$ billion). At the end of 2018, there were 854 companies listed in Warsaw and 86 in Kyiv.

In the EU, the level of individual capital markets development and their importance in the local economy varies greatly, which is best reflected in stock market capitalization, the number of listed companies or the ratio of capitalization of exchanges to GDP. In Poland, this relationship is about $38 \%$. By comparison, in the United States it is about $160 \%$; around $150 \%$ in the UK; around 100\% in France, Finland and Belgium; and less than 10\% in Lithuania, Latvia, Cyprus and Slovakia. For Ukraine, this ratio is currently difficult to determine. ${ }^{27}$

\subsubsection{The Ukrainian capital market}

The position in the ranking of the capitalization of the Ukrainian Exchange against the background of the Warsaw Stock Exchange (WSE) (Polish: Giełda Papierów Wartościowych w Warszawie - and other European exchanges) prompts one to search for the reasons for the observed weak competitive position in the area of securities trading in Europe. Harutyunyan 
proposes a periodization of the stages of development of the Ukrainian capital market, which can assist us to understand the causes of the observed weak competitive position of the Ukrainian capital market (Harutyunyan 2017).

Between 1990 and 1999, a mass privatization of state-owned enterprises was carried out, which created the National Bank of Ukraine (Ukrainian: Національний банк України, Natsionalnyy bank Ukrayiny) and the first Stock Exchange (Trading Information System (Ukrainian Торгівельноінформаційна Система, Torhovelno-informatsiyna Systema). ${ }^{28}$ In 1997, the National Securities and Stock Market Commission began to operate (Ukraine) (Ukrainian: Національна комісія з цінних паперів та фондового ринку, Natsionalna komisiya $\mathrm{z}$ tsinnykh paperiv ta fondovoho rynku).

Between 2000 and 2009 the infrastructure framework of Ukraine's institutional financial system was revised. The banking system was developed and the legal bases for the activities of exchanges were standardized. It was only at this stage that the process of educating the private shareholders of the largest industrial companies, combined with a noticeable and deliberate transformation of national savings into investments by companies, began. However, capital control and corruption were among the major barriers to capital market development during this period.

Institutional changes in the financial sphere coincided with a good economic situation in the real economy. Between 2001 and 2007, real GDP per capita in Ukraine increased by $60.7 \%$. Such favorable results were mainly due to the undertaken economic reforms related to the conversion of the Ukrainian currency (UAH), stabilization of inflation, increasing the competitiveness of domestic production and the creation of favorable conditions for the development of innovation and entrepreneurship (Pustovoit 2016: 86-109). The equity securities market and the debt market were discounting the overall prosperity. The issue of a new series of shares and bonds (government and corporate) expanded from UAH 47.3billion (in 2000) to UAH 95.6 billion (in 2010). The liquidity of the securities market dramatically increased from UAH 39.2 billion (in 2000) to UAH 1537.8 billion (in 2010). Over the whole of the year under consideration, there was a marked increase in the share of government bond issuance and their increasing share of total securities turnover (46.4\% in 2010). ${ }^{29}$ The economic prosperity of this decade created a climate of trust in the institutions of the financial system. In October 2008, a consolidated Ukrainian Exchange was established (Українська біржа, Ukrayinsa birzha) in Kyiv. The main motivation was to create a transparent securities trading platform conducive to corporate governance, to attract foreign capital and to integrate securities market operators into international competition.

The last decade (2009-2019) was characterized by political instability, nationalization trends (the case of PrivatBank, ПриватБа́нк), a decrease in confidence in the financial system, a weak economic downturn, the depreciation of the UAH, difficulties in fulfilling the conditions of cooperation with 
the International Monetary Fund (IMF), continuing restrictions on capital turnover, the inoperable criminal justice system and corruption.

In these circumstances, any development of the capital market is extremely difficult. In a development strategy paper entitled: "A Comprehensive Development Program for the Finance Sector of Ukraine by 2020" (Комплексна програма розвитку фінансового сектору України до 2020 р.; Compleksna prohrama rozvytku finansovoho sectoru Ukrainy do 2020), the need for an evolution based on those standards developed in the western part of Europe is stressed. ${ }^{30}$ From the perspective of 2018, the biggest weaknesses of the Ukrainian capital market include the downward trend in trading volume, the low level of free float, the limited and decreasing number of investors, and the construction of the main stock market index (Акції в Індексі UX) based in $72 \%$ on the results of the shares quotations of 3 companies (Центренерго, ${ }^{31}$ Мотор Січ, ${ }^{32}$ Укрнафта ${ }^{33}$ ).

The Polish capital market is the largest and most developed market in Central and Eastern Europe and is an important element in the corporate development financing system. Compared to the largest capital markets in Europe, Poland is a relatively small market with little capitalization and turnover. The Warsaw Stock Exchange is more than ten times smaller than the stock exchange in Switzerland, and the scale may compare with the markets in Turkey or Norway, but it is 35 times the size of the Kyiv Stock Exchange. Only macroeconomic stabilization combined with the implementation of the standards and principles of the member states of the European Union can change the competitive position of the capital market and its impact on the Ukrainian economy.

The Ukrainian capital market is still not an important tool for ownership transformation and an efficient mechanism for converting national savings into investments in the business sector, nor does the creation of transparency augment economic turnover.

\subsection{Summary}

The experience of the last 25 years allows for an overall positive assessment of the Polish way of ownership transformation and the development of private property institutions. The share of the Polish State as owner of the means of production between 1990 and 2015 decreased radically.

In general, an assessment of the heretofore process of ownership transformation in Ukraine and its results is not clear. On the one hand, the process of ownership transformation is still far from completed, and is considered an important impetus for the development of a market-oriented political and economic system; on the other hand, selected privatization paths, a lack of proper control over its course and corruption have caused great dissatisfaction and a lack of the universal public acquiescence required to continue this process by the methods employed until now. Privatization in Ukraine is an unfinished process. 
The Polish capital market during the first two decades of the economic transformation was significantly involved in the process of the privatization of the public sector. The sale of shares of state-owned companies was one of the most important changes in the whole process of the transformation of the ownership structure of Polish companies. The Ukrainian capital market is much less involved in the process of the ownership transformation of the Ukrainian economy and its entities. It is to be assessed as a barely efficient mechanism for supporting private sector development in Ukraine.

\section{Notes}

1 The GDP per capita is based on the purchasing power parity (PPP). The PPP GDP is the gross domestic product converted to international dollars using purchasing power parity rates. An international dollar has the same purchasing power over GDP as the US dollar has in the United States. The GDP at the purchaser's prices is the sum of the gross value added by all resident producers in the economy plus any product taxes, and minus any subsidies not included in the value of the products. It is calculated without making deductions for the depreciation of fabricated assets or for the depletion and degradation of natural resources. Data are in current international dollars based on the 2011 ICP round.

2 Purchasing power parities (PPPs) are indicators of price level differences across countries. PPPs tell us how many currency units a given quantity of goods and services costs in different countries. PPPs can thus be used as currency conversion rates to convert expenditures expressed in national currencies into an artificial common currency (the Purchasing Power Standard, PPS), eliminating the effect of price level differences across countries.

The main use of PPPs is to convert national accounts aggregates, like the Gross Domestic Product (GDP) of different countries, into comparable volume aggregates. Applying nominal exchange rates in this process would overestimate the GDP of countries with high price levels relative to countries with low price levels. The use of PPPs ensures that the GDP of all countries is valued at a uniform price level and thus reflects only differences in the actual volume of the economy.

3 The prices of the so-called base year prices, $2011=100$, serve to determine physical changes in the size of the aggregate economic volumes (GDP, investment) in a valuable sense. The purpose of applying the prices of the base year is to eliminate the impact of current price developments on the dynamics of the categories tested. The prices of the base year ensure the comparability of changes over different periods

4 Entsyklopediya istoriyi Ukrayiny: Vol. 1: A-V/Redkol.: V. A. Smoliy (holova) ta in. NAN Ukrayiny. Instytut istoriyi Ukrayiny. - K.: V-vo "Naukova dumka", 2003. 688, Access: http://www.history.org.ua/?termin=Vyscha_Rada (18.01.2020).

5 Marochko V. Ukrayins'ka Rada Narodnoho Hospodarstva - 2, Access: http:// www.history.org.ua/?termin=Ukrainska_hospodarstva

6 Ustawa z dnia 13 lipca 1990 r. o prywatyzacji przedsiębiorstw państwowych, Dz. U. z 1990 r. nr 51, poz. 298.

7 Ustawa z 19 października 1991 r. o gospodarowaniu nieruchomościami rolnymi Skarbu Państwa (Dz. U. 1991, nr 107, poz. 464).

8 Ustawa z 5 lutego 1993 r. o przekształceniach własnościowych niektórych przedsiębiorstw państwowych o szczególnym znaczeniu dla gospodarki państwa (Dz. U. 1993, nr 16, poz. 69). 
9 Ustawa z dnia 30 kwietnia 1993 r. o narodowych funduszach inwestycyjnych i ich prywatyzacji (Dz. U. 1993, nr 44, poz. 202).

10 Before they proceeded with the process of ownership transformation, the Czechs first drew up a detailed register of state property (including craft workshops and other small businesses engaged in sectors of the service industry).

11 State-owned enterprises entered in the register of entrepreneurs

12 Ownership transformations of state-owned enterprises, MSP, 2016, Access: 201812-01, https://bip.msp.gov.pl/bip/raporty-analizy/przeksztalcenia-wlasnos/10245, stan-na-dzien-31-grudnia-2015-roku.html]

13 Prywatyzacja przedsiębiorstw państwowych w 2012 roku, Notatka informacyjna, GUS, 2013, p. 1.

14 Ibidem.

15 Ownership transformations of state-owned enterprises, MSP, 2016, Access: https:// bip.msp.gov.pl/bip/raporty-analizy/przeksztalcenia-wlasnos/10245.

16 Ustawa z dnia 24 lutego 1989 r. o niektórych warunkach konsolidacji gospodarki narodowej oraz o zmianie niektórych ustaw, Dz.U. $1989 \mathrm{nr} 10$ poz. 57.

17 Zakon Ukrayiny Pro pryvatyzatsiyu derzhavnoho mayna, Vidomosti Verkhovnoyi Rady Ukrayiny 1992, No. 24, p. 348 (Закон України Про приватизацію державного майна (Відомості Верховної Ради України (ВВР), 1992, № 24, ст. 348), Access: http://zakon.rada.gov.ua/laws/show/2163-12.

Zakon Ukrayiny; Pro Derzhavnu prohramu pryvatyzatsiyi, Vidomosti Verkhovnoyi Rady Ukrayiny (Закон України; Про Державну програму приватизації, Відомості Верховної Ради України (ВВР), 2000, N 33-34:. 272 ) Access:: http:// zakon.rada.gov.ua/laws/show/1723-14.

Zakon Ukrayiny, Pro Derzhavnu prohramu pryvatyzatsiyi (Закон України, Про Державну програму приватизації) 2010-2014 from 5.08.2010, Source: http:// www.spfu.gov.ua/documents/962.html

Zakon Ukrayiny, Pro pryvatyzatsiyu derzhavnoho i komunal'noho mayna (Vidomosti Verkhovnoyi Rady (Закон України, Про приватизацію державного i комунального майна (Відомості Верховної Ради (ВВР), 2018, № 12, ст.68) from 18.01.2018 r Source: http://zakon.rada.gov.ua/laws/show/2269-19.

18 The statistical yearbook "Ukraine in numbers" (Rocznik statystyczny "Ukraina w liczbach"). Source: http://www.UKRSTAT.gov.ua. Personal conversation with employees UKRSTATu. http://www.UKRSTAT.gov.ua. Personal conversation with employees of UKRSTAT.

19 Consolidated datasets About Legal People started only in 1998, hence the lack of data for 1995. Since 1996, UKRSTAT has kept a record of data for all economic operators together, without distinguishing between the forms of ownership in the manufacturing-processing sector.

20 Data for year 2015 does not contain information on occupied Crimea and the ATO territory.

21 Financial System Development Reports, Access: https://www.nbp.pl/homen. aspx?f=/en/systemfinansowy/rozwoj.html.

22 Ustawa z dnia 4 lipca 1992 r. o ratyfikacji Układu Europejskiego ustanawiajacego stowarzyszenie między Rzeczapospolita Polska a Wspólnotami Europejskimi i ich Państwami Członkowskimi, sporzadzonego w Brukseli dnia 16 grudnia $1991 \mathrm{r}$. (Dz. U. 1992, nr 60, poz. 302).

23 Dz. U. z 2005 r., nr 183, poz. 1538.

24 Dz. U. z 2005 r., nr 184, poz. 1539.

25 Dz. U. z 2005 r., nr 183, poz. 1537.

26 These are estimates based on World Bank Data (2019), and the World Federation of Exchanges database (Access: 2019-01-07, https://data.worldbank.org/ indicator/CM.MKT.LCAP.CD?view=chart); StockMarketClock.com (2019), List of Stock Exchanges (Access: 2019-01-07, https://www.stockmarketclock. 
40 Svitlana Chugaievska et al.

com/exchanges) and World Federation of Exchanges (2019), Market Statistics December 2018 (Access: 2019-01-07, https://focus.world-exchanges.org/issue/ december-2018/market-statistics).

27 See. http://www.ux.ua/en/ (Market Capitalization, UAH, bln).

28 Stock trading, however, in Ukraine dates back to 1992. Until 2008, the "Exchange" did not have a guaranteed system for the execution of transactions. The trading technology was based on bulletin boards or a message exchange system. This generated a huge operational risk for securities trading.

29 Along with annual reports of Natsional'na Komisiya Z Tsinnykh Paperiv Ta Fondovoho Rynku (Національна Комісія 3 Цінних Паперів Та Фондового Ринку). Access: http://www.ssmsc.gov.ua/).

30 Kompleksna prohrama rozvytku finansovoho sektoru Ukrayiny do 2020 roku: Postanova Pravlinnya Natsional'noho banku Ukrayiny vid 18 chervnya (Комплексна програма розвитку фінансового сектору України до 2020 року: Постанова Правління Начіонального банку Украӥни від 18 червня 2015). Retrieved from: https://bank.gov.ualdoccatalog/document?id=43352266; Lyashenko, S. V. (2011), Capital market in Ukraine and ways of cooperation with the countries of the commonwealth of independent states (CIS). Economic Herald of the Donbas, Vol. 4 (26), s. 151-162.

$31 \mathrm{http}: / / \mathrm{www} . c e n t r e n e r g o . c o m /$.

$32 \mathrm{http} / / / \mathrm{www} . \mathrm{motorsich.com/ukr/.}$

33 https://www.ukrnafta.com/. 